\title{
Enterprise Architecture within the Process of Permanent Change
}

\author{
Jan Váchal ${ }^{1}$ and Jarmila Straková ${ }^{1}$ \\ ${ }^{1}$ Institute of Technology and Business in České Budějovice, Faculty of Corporate Strategy, \\ Department of Management, Okružní 517/10, 37001 České Budějovice, Czech Republic
}

\begin{abstract}
Permanent changes that happen within the external surroundings of an enterprise, respectively within the macro-environment, significantly influence its efficiency and behaviour. The framework for these changes is made up by Enterprise Architecture (EA). Impacts of these changes are distinct in both, the internal environment of an enterprise as well as in its mid-environment, being of dynamic nature, and their elimination is a basic assumption of keeping the enterprise's competitiveness. The article focuses on analysing the macro-environment factors' influence on the changes in enterprise EA from the perspective of their sector differentiation. Tests have been carried out both ways - for chosen macro-environment factors, as well as macro-environment areas as a whole. The research survey was carried out on a file of 456 enterprises from the whole of the Czech Republic, out of which the production and industry sectors included 187 enterprises, and the service sector 255 enterprises. Pearson's chi-quadrate test was used as a statistical method. At the same moment, macro-environment factor prediction was tested, respectively the importance attached by top managers to the individual macro-environment factors in the future. Research results have proven a significant sector differentiation from the perspective of macroenvironment factors' impact on EA, while a greater influence of these factors has been indicated mainly in the service sector. It may be assumed that top managers begin to prove a risk symptom caused by a change in the economic cycle.
\end{abstract}

Key words: uncertainty, probability, fuzziness, expected value, fuzzy number

\section{Introduction}

Enterprise changes may be of different dimension, intensity, and range. One of the most significant and decisive changes within the enterprise is the change in enterprise architecture (EA), expressing all basic enterprise dimensions within its system conception. Mainly we are talking about enterprise vision, strategy, aims, enterprise functions, processes, and organization structure, database, software, hardware, and space localization. The term of EA has been used sing the end of the past century [25], but its definition as well as content is non-uniform, and greatly differentiated. Some authors define it as a complex enterprise definition matching the given time period $[3,17,22,23]$. Other authors define it as a strategical quantity within enterprise activity [2, 3, 13-15]. According to the Gartner company [7], enterprise architecture is a process of efficient transformation of 
enterprise vision and mission into enterprise change via creation, communication, and improvement of key requirements, principles and models that describe the enterprise's future situation, and enable its development. Some authors [6, 12, 24] integrate enterprise architecture within information enterprise systems to reach enterprise aims while managing IT sources more efficiently, flexibly, and transparently. Recent works include professional interviews, case studies and surveys that are prepared with a broader focus on the EA management in organizations both in the commercial and IT context $[8,20]$.

Changes happening in enterprise architecture result mainly from a globalizing external enterprise environment. They reach both, the enterprise mid-environment and internal enterprise resources; in total they reach the complete enterprise architecture. In real enterprise practice dynamic process [4] in EA change set happens aiming to keep competitiveness and sustainability $[15,18]$. These changes are marked by a range of authors as strategic changes [2, 3, 15, 23], as decisive changes by other authors [13, 18]. Classification of these changes is introduced by Veber [23], and the term of 'a great change' is being introduced too, Christensen $[10,11]$, on the contrary, understands it as a 'breakthrough' change. According to Dan Schendel and Charles W. Hofer [21] a process dealing with enterprise strategy, such as a change in enterprise focus, in resource use, competition advantage, market position, suppliers and buyers may be understood the strategic change.

The aim of enterprise architecture and its innovation is to react to constantly changing competition environment. Enterprise architecture transformation process is dependent on targeted implementation projects including all basic process areas of the given enterprise [9, 19]. To manage organization changes, Lapalme [16] perceive enterprise architecture and project portfolio management as the most important pro-growth and value-creating enterprise tool. The architecture framework TOGAF describes the methods of creation, management and application of framework and information systems used for creating a model of developing business architecture [1]. TOGAF (The Open Group Architecture Framework) is owned and managed by The Open Group consortium. This non-profit consortium consists of a number of experts from the whole world. TOGAF has many key components, one of them being the ADM (Architecture Development Method) as a process-based model for creating and managing the development and changes of business architecture [5]. Enterprise architecture is a managers' tool for an efficient and flexible decision-making within changes in an enterprise so that the enterprise is able to exist in a long-term period. The submitted article focuses on the external environment's influence on the EA nowadays even predicting future development.

\section{Methodology}

The testing set included 456 enterprises from the whole of the Czech Republic. Enterprises were broken down from the perspective of size categorization, sector differentiation, and scope. The set from the perspective of enterprise size categorization included 109 microenterprises (up to 10 employees), 140 small enterprises (up to 50 employees), 124 medium enterprises (up to 250 employees), and 83 big enterprises (more than 250 employees). From the perspective of sector differentiation, 187 enterprises came from the sector of production and industry, 255 enterprises from the service sector. The research survey was done through a vast questionnaire survey focused on the issue of enterprise environment, respectively its individual components (internal enterprise resources, mid-environment, and macroenvironment), and strategy. Using Pearson's chi-quadrate test, macro-environment factor dependence/independence has been determined (individually as well as for the macroenvironment area as a whole) on the profitability of enterprises, respectively their influence on EA from the perspective of sector differentiation. Tests have been carried out on a 
standard level of significance of 0.05 , i.e. with reliability of $95 \%$. Research hypothesis relied in the assumption that factors analysed as significant from the perspective of enterprise profitability reflect the need of their stabilization or change within enterprise architecture, at the same time.

Prediction, respectively what significance enterprise top managers assign to individual macro-enterprise factors in the future, was tested as well. For each manager, their total deviation from the optimal model via quadrate loss function may be determined. Based on this, 60 of the best top managers, 30 from the service sector and 30 from production enterprise sector were chosen. These managers were trusted in future development predictions. Within prediction determination, average values of individual variables from a subset were calculated, used further as a prediction of the optimal macro-environment situation in the future.

\section{Results and Discussion}

The following tables (table 1 and 2) state the results of macro-environment dependence factors on enterprise profitability, respectively on necessary changes in EA for industry and production sector (table 1) and Service Sector (table 2). Tab. 1 shows that none of the analysed factors has proven statistically significant value. In the rate of obsolescence of means of production and technology transfer, a higher influence on EA changes may be assumed. These factors have been also mentioned frequently within structured interviews with representatives of top management. Results of related internal enterprise resource analyses and mid-environment, which are not the subject of this contribution, have indicated a significantly higher importance in internal enterprise resources in comparison to macro-environment factors.

In service sector (table 2), the following factors influencing the change of EA have been proven: enterprise lifecycle, tax policy, the rate of obsolescence of services provided, inflation, and technology transfer.

Table 1. Dependence of macro-environment factors on profitability, respectively changes in EA enterprises operating in production and industry sector.

\begin{tabular}{|l|r|r|}
\hline \multicolumn{1}{|c|}{ Macro-environment Factors } & p-Value & Chi-Quadrate \\
\hline Demographic Development & 0.8687 & 3.8694 \\
\hline Income Distribution & 0.419 & 8.1499 \\
\hline Lifestyle & 0.4067 & 8.2793 \\
\hline Level of Education & 0.7105 & 5.4322 \\
\hline Citizen Mobility & 0.7181 & 5.3632 \\
\hline Leisure Time Approaches & 0.8195 & 4.3982 \\
\hline Governmental Expenditures on Research, Development & 0.9651 & 2.4259 \\
\hline New Patents, Discoveries & 0.6297 & 6.1569 \\
\hline Technology Transfer & 0.2526 & 10.18 \\
\hline Rate of obsolescence of the means of production & 0.108 & 13.1142 \\
\hline GDP Development & 0.4945 & 7.3971 \\
\hline Interest Rates & 0.864 & 3.9235 \\
\hline Inflation & 0.7114 & 5.4248 \\
\hline Enterprise Lifecycle & 0.3301 & 9.1464 \\
\hline Unemployment & 0.9358 & 2.9769 \\
\hline
\end{tabular}




\begin{tabular}{|l|l|r|}
\hline Government Stability & 0.7162 & 5.3809 \\
\hline Foreign Trade Regulation & 0.8432 & 4.1514 \\
\hline Tax Policy & 0.3843 & 8.5207 \\
\hline Legislation & 0.4224 & 8.1139 \\
\hline
\end{tabular}

Source: Authors.

Table 2. Macro-environment factor dependence on profitability, respectively EA changes in enterprises operating in service sector

\begin{tabular}{|l|r|r|}
\hline \multicolumn{1}{|c|}{ Macro-environment Factors } & p-Value & Chi-Quadrate \\
\hline Demographic Development & 0.6355 & 4.3049 \\
\hline Income Distribution & 0.5733 & 6.6636 \\
\hline Lifestyle & 0.7021 & 5.5089 \\
\hline Level of Education & 0.05759 & 12.2029 \\
\hline Citizen Mobility & 0.2911 & 7.334 \\
\hline Leisure Time Approaches & 0.4484 & 5.7791 \\
\hline Governmental Expenditures on Research, Development & 0.3557 & 8.8434 \\
\hline New Patents, Discoveries & 0.05365 & 15.2954 \\
\hline Technology Transfer & $\mathbf{0 . 0 1 5 5 2}$ & 18.8799 \\
\hline Rate of Service Obsolescence & $\mathbf{0 . 0 1 4 9 9}$ & 18.9758 \\
\hline GDP Development & 0.2726 & 7.5549 \\
\hline Interest Rates & 0.1738 & 8.9965 \\
\hline Inflation & $\mathbf{0 . 0 1 5 1 4}$ & 15.7527 \\
\hline Enterprise Life Cycle & $\mathbf{0 . 0 0 3 1 6 1}$ & 8.1819 \\
\hline Unemployment & 0.4159 & 8.1819 \\
\hline Government Stability & 0.1104 & 13.0415 \\
\hline Foreign Trade Regulation & 0.02244 & 14.7326 \\
\hline Tax Policy & $\mathbf{0 . 0 1 4 8}$ & 15.8122 \\
\hline Legislation & 0.05753 & 12.2059 \\
\hline
\end{tabular}

Source: Authors.

Tested factors were organized into 4 basic areas: socio-cultural, technological, economical, and political-legal. Table 3 states the dependence of the above-mentioned areas as a total on profitability (EA change) of enterprises. 
Table 3. Dependence of macro-enterprise areas on profitability, respectively changes in EA enterprises.

\begin{tabular}{|l|r|r|}
\hline \multicolumn{1}{|c|}{ Factors } & \multicolumn{1}{c|}{ p-Value } & Chi-Quadrate \\
\hline \multicolumn{2}{|c|}{ Production and Industry Sector } \\
\hline Socio- Cultural & 0.5791 & 4.7287 \\
\hline Technological & 0.04612 & 12.812 \\
\hline Economical & 0.06491 & 11.8708 \\
\hline Political-Legal & 0.03092 & 13.887 \\
\hline \multicolumn{3}{|c|}{ Service Sector } \\
\hline Socio-Cultural & 0.02671 & 14.2751 \\
\hline Technological & 0.00000003647 & 45.5452 \\
\hline Economical & 0.000001417 & 37.4832 \\
\hline Political & 0.000003536 & 35.4432 \\
\hline
\end{tabular}

Source: Authors.

As opposed to results within an individual evaluation of each factor independently, significant values were proved in technological and political-legal area, in all areas for service sector, in a group factor rating (see table 3). In production sector an assumption may be made that mainly the technological area including the innovation process, and politicallegal area are significant ones, in service sector, a higher level of interdependence between this sector and macro-environment, and the straightforward effect of its factors on EA changes.

Another part of the research was focused on predicting optimal situation of macroenvironment from the perspective of opinion level to managers (table 4). As it has been suggested by prediction outcomes, in both sectors tested significant changes may be expected, different in individual sectors, in both individual factor significance as well as the intensity of their action.

In production and industry sector, technology transfer and intellectual property may be understood as future core factors. Follow-up important factors include also macroeconomic indicators (interest rates, inflation, GDP development), factors from the sociocultural area are relatively significant as well. In service sector, enterprise life cycle, income distribution, technology transfer and level of education belong among core factors.

Despite a great sector differentiation, a range of common factors that will have to be solved within EA, may be found. As the results suggest, some factors will be necessary to be strengthened via EA changes, some stabilized, in some factors their current meaning will be lowered and rather harmonized with other follow-up factors.

During a detailed analysis of macro-environment factors, fears of economic cycle change and succession of economic recession begin to appear in managers' approaches throughout both sectors. A growing influence of macro-indicators, anti-crisis and progrowth factors, such as technology transfer, patent or enterprise life cycle may be set as examples. The importance of these factors, however, should be of core character, these factors should play a significant role in the change of enterprise architecture. 
Table 4. Macro-environment Optimal Situation Prediction from the Perspective of Opinion Levels of Managers from the Perspective of Sector Differentiation

\begin{tabular}{|l|r|r|}
\hline \multicolumn{1}{|c|}{ Macro-environment Factors } & $\begin{array}{c}\text { Variable Average Values } \\
\text { for Production and } \\
\text { Industry Sector }\end{array}$ & $\begin{array}{c}\text { Variable Average } \\
\text { Values for Service } \\
\text { Sector }\end{array}$ \\
\hline Demographic Development & 2.566667 & 2.666667 \\
\hline Income Distribution & 2.666667 & $\mathbf{2 . 7 6 6 6 6 7}$ \\
\hline Lifestyle & 2.666667 & 2.6 \\
\hline Level of Education & 2.533333 & $\mathbf{2 . 7}$ \\
\hline Citizen Mobility & 2.666667 & 2.566667 \\
\hline Leisure Time Approaches & 2.666667 & 2.533333 \\
\hline Governmental Expenditures on Research, & 2.633333 & 2.666667 \\
\hline New Patents & $\mathbf{2 . 7 3 3 3 3 3}$ & 2.666667 \\
\hline Degree of Obsolescence of Means of Production & $\mathbf{2 . 7 3 3 3 3 3}$ & $\mathbf{2 . 7 6 6 6 6 7}$ \\
\hline Degree of Obsolescence of Means of Production & 2.433333 & 2.666667 \\
\hline GDP Development & 2.633333 & 2.633333 \\
\hline Interest Rates & $\mathbf{2 . 7 3 3 3 3 3}$ & 2.666667 \\
\hline Inflation & 2.633333 & 2.466667 \\
\hline Enterprise Life Cycle & 2.666667 & $\mathbf{2 . 9}$ \\
\hline Unemployment & 2.466667 & 2.5 \\
\hline Government Stability & 2.566667 & 2.6 \\
\hline Foreign Market Regulation & 2.5 & 2.633333 \\
\hline Tax Policy & 2.5 & 2.433333 \\
\hline Legislation & 2.466667 & 2.4 \\
\hline
\end{tabular}

Source: Authors.

\section{Conclusion}

Results from the external factor research within the context of changes in enterprise architecture may be perceived as input and orientational, for the research survey was happening at a period of a significant economic growth, and this fact did influence the value of outputs obtained in real terms. Despite this statement, the following conclusions may be made:

- Based on the prediction of future situation, significant changes in enterprise architecture may be expected, relying mainly in the change of significance of individual factors, but also in the intensity of these changes and their effect. Sector enterprise differentiation is being strictly projected within these changes.

- In production and industry sector, significant factors of EA changes may be understood from the current perspective as well as prediction mainly by factors from the technological area (technology transfer and the degree of obsolescence of means of production).

- EA changes in service sector will be caused, in the future, by factors blending through all macro-environment areas tested, mainly within the enterprise life cycle, income distribution, and technology transfer. Changes will be increased by demographic development, governmental expenditures and research expenditures, 
the area of intellectual property, the degree of obsolescence of means of production, and the level of interest rates.

Theses with similar focus do not commonly occur in expert printing, authors are, however, aware of the heaviness, and the up-to-date characteristics of this issue. They do believe that once finished, the outputs may be used while ensuring the competitiveness of Czech enterprises, perhaps their stabilization, and while preparing for a period of time when economic growth is less intense and pro-growth.

\section{References}

1. E. Amalia, H. Supriadi, Development of enterprise architecture in university using TOGAF as framework. AIP Conference Proceedings [online], 1855, 1, Available at: https://aip.scitation.org/doi/abs/10.1063/1.4985527 (2017)

2. R. Bevan, Change Making: Tactics and Resources for Managing Organizational Change. CreateSpace Independent Publishing Platform, (2011)

3. R. L. Daft, Organization Theory and Design. Cengage Learning, (2007)

4. Y. Doz, M. Kosonen, Fast Strategy. How Strategic Agility Will Help You Stay Ahead of the Game. FT Press, (2011)

5. A. Ferrugento, A. Rocha, Evolution of Methodological Proposals for the Development of Enterprise Architecture. New Contributions in Information Systems and Technologies, 351-359, (2018)

6. F. Gampfer, A. Jürgens, M. Müller, R. Buchkremer, Past, current and future trends in enterprise architecture: A view beyond the horizon. Computers in Industry, 100, 70-84, (2018)

7. I. Gartner, Enterprise Architecture (EA) / Gartner IT Glossary. IT Dictionary, IT Terms / Gartner IT Glossary [online], Available at: http://www.gartner.com/itglossary/enterprise-architecture-ea/ (2012)

8. B. T. Hazen, R. V. Bradley, J. E. Bell, J. In, T. A. Byrd, Enterprise architecture: A competence-based approach to achieving agility and firm performance. International Journal of Production Economics, 193, 556-577, (2017)

9. M. Hugoson, et al., Enterprise architecture design principles and business-driven IT management. International Conference on Business Information Systems, 57, 144-155, (2010)

10. C. M. Christensen, The Innovator's Dilemma: When New Technologies Cause Great Firms to Fail. HighBridge Audio, Abridged edition, (2006)

11. C. M. Christensen, J. Grossman, J. Hwang, The Innovator's Prescription: A Disruptive Solution for Health Care. McGraw-Hill Education, (2009)

12. E. Kaoutar, B. Bounabat, Strategic Alignment Assessment Based on Enterprise Architecture. International Conference on Information Management and Evaluation, 179-187, (2010)

13. J. P Kotter, Leading Change: Why Transformation Efforts Fail. Harward Business Review, (1995)

14. J. P Kotter, Srdce změny: Skutečné př́běhy o tom, jak lidé mění své organizace. Management Press, (2003)

15. J. P. Kotter, Vedení procesu změny. Management Press, (2004)

16. J. Lapalme, Three Schools of Thought on Enterprise Architecture. IEEE Computer Society, (2012) 
17. M. Lankhorst, Enterprise Architecture at Work: Modelling, Communicationand Analysis. Springer-Verlag Berlin Heidelberg, (2009)

18. R. Luecke, Managing Change and Transition: 7 Practical Strategies to Help You Lead During Turbulent Times. Harvard Business School Press, (2003)

19. J. W. Ross, et al., Enterprise architecture as strategy: creating a foundation for business execution. Harvard Business School Press, (2006)

20. G. Shanks, M. Gloet, I. A. Someh, K. Frampton, T. Tamm, Achieving benefits with enterprise architecture. The Journal of Strategic Information Systems, 27(2) 139-156, (2018)

21. D.E. Schendel, Ch.W. Hofer, Strategic management. A new view of business policy and planning. Little, Brown \& Company, (1979)

22. M. Van den Berg, M. Van Steenbergen, Building an enterprise architecture practice. Springer, (2006)

23. J. Veber, et al., Management: Základy, moderní manažerské přistupy, výkonnost a prosperita. Management Press, (2011)

24. R. Winter, J. Schelp, Enterprise architecture governance: the need for a business-to-IT approach. Proceedings of the 2008 ACM symposium on Applied computing, 548-552, (2008)

25. J. A. Zachman, A framework for information systems architecture. The IBM systems Journal, 26(3), 276-292, (1987) 